\title{
РЕЦЕНЗИЯ НА УЧЕБНИК \\ РОЩИН В.Е., РОЩИН А.В.«ЭЛЕКТРОМЕТАЛЛУРГИЯ И МЕТАЛЛУРГИЯ СТАЛИ»
}

В последнее время ощущается острый дефицит научно-технической литературы. Пожалуй, в еще большей степени это касается учебных изданий. В то же время потребность в учебной литературе, в которой доступно для студентов разных уровней подготовки бакалавров, магистров и аспирантов научно-значимо и содержательно, на современном уровне развития металлургической науки и технологии были освещены основные проблемы развития сталеплавильных процессов, велика.

Учебник по металлургии и электрометаллургии представлен читателю как расширенное и дополненное четвертое издание известного учебника «Электрометаллургия стали и ферросплавов» (1971, 1984, 1995 гг.). Однако по сравнению с третьим изданием это совсем другой учебник. На современном этапе развития металлургии повсеместно используются ковшовая обработка стального полупродукта, доводка по химическому составу, рафинирование и вакуумирование стали. Производительность современных дуговых печей практически сравнялась с производительностью кислородных конвертеров. Оба типа сталеплавильных агрегатов производят практически одинаковый окисленный полупродукт, который в дальнейшем подвергается внепечной обработке по одинаковой технологии, несмотря на то, что основную часть металлошихты конвертера составляет чугун, а электропечи - металлолом. Постепенно количество лома, добавляемого в конвертер, увеличивается, а в электроплавке достаточно широко используется жидкий чугун. Вследствие этого физико-химические закономерности процессов выплавки и рафинирования стали становятся весьма близкими, отсюда и закономерное название учебника «Электрометаллургия и металлургия стали».

Представленный читателю учебник сложился не сразу. В 2005 г. Рощин В.Е. и Рощин А.В. издали курс лекций «Физические основы плавления и отвердевания металлов». В 2008 г. выходит учебное пособие тех же авторов «Структура и дефекты стальных слитков и заготовок». В этом же году издается учебное пособие для вузов «Разливка и кристаллизация стали», а в 2009 г. - учебное пособие «Основы производства нанокристаллических и аморфных металлов». В 2012 г. на основе курса лекций, который читался в Карагандинском университете профессором Рощиным В.Е. по приглашению университета, в Казахстане издается учебник «Выплавка и разливка стали». Лишь после такой длительной подготовительной методической работы сложился учебник «Электрометаллургия и металлургия стали».
Материал учебника изложен на 572 страницах и состоит из трех частей:

Часть I. Печи и агрегаты сталеплавильного производства.

Часть II. Основы теории производства стали.

Часть III. Технология производства стали.

Каждая часть разбита на разделы и главы со сквозной нумерацией. Поэтому можно сказать, что учебник состоит из 7 разделов и 47 глав. В целом это очень удобная форма систематизации весьма обширного и разнообразного учебного и научного материала. При этом каждый из разделов учебника по объему и содержательности может претендовать на самостоятельное учебное издание.

Раздел I посвящен описанию конструкций электродуговых печей и конвертеров, особенностей футеровок, систем подвода энергии, технологических газов, систем улавливания пыли и утилизации тепла отходящих газов, а также различных вариантов исполнения конкретных типов печей.

Во втором разделе описаны печи, плавильные установки и оборудование специального назначения: индукционные, открытые и вакуумные печи, технические устройства вакуумных систем, конструкции вакуумных дуговых и электронно-лучевых печей, установки электрошлакового переплава для получения слитков и изделий специального назначения.

В третьем разделе учебника изложена фактически своеобразная физика металлов. Обсуждены проблемы металлической связи, кристаллического состояния металлов, процессов, происходящих при нагреве металла, его плавлении и кристаллизации. Приведены количественные теории этих процессов.

В четвертом разделе изложены физико-химические основы взаимодействия в металлических и шлаковых расплавах. Очень подробно и доступно рассмотрены свойства жидких сплавов на основе железа, их физические свойства, активности растворенных в железе примесей. Рассмотрены химические и технологические свойства жидких шлаков, окислительно-восстановительные процессы на границе металла и шлака, раскисление стали, растворы газов в стали, особенности воздействия вакуума на жидкую сталь и рафинирование жидкой стали в вакууме.

В пятом разделе изложены общие основы технологии выплавки стали в электропечах и в конвертерах, а также технологические особенности проведения процессов в этих агрегатах.

В шестом разделе излагаются особенности внепечной обработки стали, описываются устройства ков- 
шей, агрегатов доводки стали, агрегатов ковш-печь, различных вакууматоров, технологии обработки стали и наведения шлака в промежуточном ковше, кристаллизаторе. Рассмотрены также особенности разливки стали в слитки и способы воздействия на формирование структуры слитка. Приведены конструкции машин непрерывного литья заготовок, литейно-прокатных агрегатов, установок для получения аморфной и нанокристаллической ленты.

В седьмом разделе рассмотрены технологии производства металла специального назначения, такого как коррозионностойкие, инструментальные, электротехнические стали, стали с ультранизким содержанием углерода. Здесь же описаны технологии производства металла методами специальной металлургии - в плазменных, индукционных и дуговых вакуумных печах, на установках электрошлакового переплава, в электронных плавильных установках.

Учебник снабжен большим количеством таблиц, рисунков, графиков, чертежей, выполненных на высоком полиграфическом уровне. Следует особо подчеркнуть, что учебник написан хорошим, легко воспринимаемым языком, что особенно важно для студентов.

Несомненно, учебник «Электрометаллургия и металлургия стали» будет полезен не только студентам, но и специалистам металлургических предприятий как средство повышения личной квалификации и расширение кругозора.

Авторам учебника профессорам B.Е. Рощину и А.В. Рощину удалось создать исключительно полезную и содержательную публикацию о состоянии современного сталеплавильного производства. Хотя жаль, что классические рудно- и электротермические процессы, такие как производство ферросплавов, карбида кальция, электрокорунда, карбида кремния, титанистых шлаков, которые излагались в предыдущих изданиях учебника, оказались несколько в стороне и не вошли в это издание. Они, по-видимому, ждут своего автора.

Зав. кафедрой физхимии ЮУрГУ, проф., д.т.н.

Г.Г. Михайлов Поступила 11 сентября 2013 г. 